\title{
Kenakalan remaja klithih yang mengarah pada konflik sosial dan kekerasan di Yogyakarta
}

\author{
Datu Jatmiko \\ Program Studi Pendidikan Sosiologi \\ Fakultas Ilmu Sosial Universitas Negeri Yogyakarta, Indonesia \\ Email: jatmikodatu@uny.ac.id
}

\begin{abstract}
Abstrak
Tulisan ini bertujuan untuk mendapatkan informasi mengenai peristiwa klithih yang akhir-akhir ini terjadi di Kota Yogyakarta dan sekitarnya. Klithih merupakan jenis kenakalan remaja yang mengarah pada konflik sosial dan kekerasan di masyarakat. Klithih pada awalnya adalah sebuah ajang yang digunakan oleh para remaja untuk menunjukkan eksistensinya di dalam pergaulan antar remaja di Yogyakarta. Pada akhirnya klithih akhirnya berubah menjadi ajang untuk menciptakan sebuah konflik sosial dan kekerasan dengan menyasar siapa saja yang berada di jalan raya. Penyebab umum terjadinya klithih selain untuk menunjukkan eksistensi kelompok remajanya/ peer group juga karena lemahnya pengawasan dan control sosial oleh keluarga dan sekolah karena sebagian besar pelakunya adalah remaja anak sekolah. Dalam perspektif sosiologi, tidak ada jawaban tunggal dalam menjelaskan realitas sosial termasuk fenomena klithih ini karena sosiologi merupakan ilmu sosial berparadigma ganda. Demikian juga dalam menjelaskan realitas klithih di Yogyakarta. Tinjauan klithih di jalanan Kota Yogyakarta ini vital dilakukan agar supaya penjelasan tidak parsial sehingga dapat mengungkapkan pemahaman yang universal dan menyeluruh. Pilihan teoretik tersebut memiliki implikasi metodologis yang selanjutnya diharapkan berakhir pada ditemukannya langkah penyelesaian yang tepat oleh
\end{abstract}


seluruh pihak yang terkait. Langkah solutif untuk pencegahan dan mengatasi terjadinya klithih perlu dilakukan untuk mengembangkan relasi sosial menjadi lebih harmonis dan humanis sekaligus mengurangi terjadinya penyakit sosial yang berupa klithih.

Kata Kunci: Klithih, Konflik sosial, Kekerasan, Yogyakarta

\begin{abstract}
This paper aims to get information about klithih events that recently occurred in the city of Yogyakarta and surrounding areas. Klithih is a type of juvenile delinquency that leads to social conflict and violence in society. Klithih was originally an event used by teenagers to show their existence in the association between teenagers in Yogyakarta. Eventually klithih finally turned into a place to create a social conflict and violence by targeting anyone who was on the highway. The most common cause of klithih in addition to showing the existence of adolescents/peer groups is also due to the weak supervision and social control by families and schools because most of the perpetrators are teenage school children. In the perspective of sociology, there is no single answer in explaining social reality including this klithih phenomenon because sociology is a social paradigm with multiple paradigms. Likewise in explaining the reality of klithih in Yogyakarta. This klithih review on the streets of Yogyakarta is vital so that the explanation is not partial so that it can reveal a universal and comprehensive understanding. The theoretical choice has methodological implications which are then expected to end in the discovery of an appropriate settlement step by all parties concerned. Solutive steps to prevent and overcome the occurrence of klithih needs to be done to develop social relations to be more harmonious and humanist while reducing the occurrence of social diseases in the form of klithih.
\end{abstract}

Keywords: Klithih, Social Conflict, Violence, Yogyakarta

\title{
Pendahuluan
}

Usia remaja adalah masa transisi seseorang dari masa kanak-kanak menuju masa dewasa. Pada masa ini, remaja mencari jati diri atau identitasnya. Hal ini ditandai dengan perbuatan-perbuatan tertentu untuk menentukan sendiri siapa diri mereka yang sesungguhnya. Kemudian bagaimana sikap baik secara lahir maupun batin anak, serta apa yang menjadi tumpuan serta fungsi anak dalam konteks kehidupan sosial. Dalam kondisi ini, anak cenderung 
sibuk untuk mencari kemandirian dan tidak ingin ada campur tangan dari siapapun termasuk keluarga mereka sendiri termasuk orang tua sendiri. Hal ini disebabkan karena anak-anak adalah fase antara kelahiran dan permulaan kedewasaan sehingga masa-masa ini merupakan masa perkembangan hidup. George Herbert Mead menyebutnya dalam masa Game Stage atau tahap bermain untuk mencari jati diri dan identitas diri. Masalah yang ditimbulkan akibat anak masuk fase ini adalah adanya keterbatasan berpikir anak yang terkadang dapat membahayakan orang lain (Putri Ratna Zunita, 2015:11). Di sini, peran orang tua dan guru harus benar-benar ekstra dalam membimbing anak agar tidak terpengaruh oleh lingkungannya yang tidak baik. Pengaruh teman sebaya atau peer group di dalam perkembangan karakter dan kepribadian anak di masa ini sangat dominan sehingga orang tua dituntut untuk mengetahui dengan siapa anaknya bergaul dan bermain.

Munculnya dekadensi moral alias degradasi moral atau kebanyakan orang menyebutnya kemerosotan moral pada remaja adalah salah satu permasalahan yang dihadapi oleh Bangsa Indonesia. Permasalahan ini timbul karena beberapa faktor, yaitu salah satunya adalah pengaruh globalisasi yang menyebabkan pengaruh dari berbagai belahan dunia dengan mudah masuk ke Indonesia. Globalisasi adalah proses penyeragaman segala sesuatu termasuk budaya sehingga tidak terbatas oleh ruang dan waktu. Globalisasi tentunya ibarat pisau bermata dua, di satu sisi berdampak positif tapi di sisi lain berdampak negative juga. Damapak negative tersebut antara lain terjadinya degradasi moral pada remaja. Salah satu bentuk degradasi moral yang muncul yaitu kenakalan remaja atau Juvenile Deliquency (Dadan Sumara, 2017:3). Kenakalan remaja adalah salah satu bentuk penyimpangan sosial atau penyakit sosial. Ada dua jenis penyimpangan sosial yakni yang sifatnya bisa dimaafkan dan tidak bisa dimaafkan/ditoleransi. Bisa dimaafkan apabila kenakalan remaja tersebut tidak melanggar norma hukum sedangkan tidak bisa dimaafkan apabila perbuatan tersebut melanggar norma hokum yang ada atau kriminalitas. Berbagai macam kenakalan remaja seperti tawuran, vandalisme, narkoba, oplosan, seks bebas, dan termasuk Klithih yang semakin banyak terjadi. Kasus Klithih menjadi suatu keprihatinan masyarakat, salah satunya di Daerah Istimewa Yogyakarta. Menurut data dari catatan Satuan Reserse dan Kriminal Kepolisian Resort Kota Besar Yogyakarta, kasus kenakalan remaja yang terjadi, termasuk tindakan Klitih di Yogyakarta selama dua sampai tiga tahun terakhir mengalami peningkatan.

Klithih menjadi salah satu kegiatan geng remaja yang tidak selalu berdasarkan identitas yang sama. Identitas yang digunakan tidak harus selalu 
sama, yang pasti mereka mampu memenuhi persyaratan masuk geng tersebut (R. Budi Sarwono, 2017:191). Kasus Klithih ini menarik perhatian dengan adanya peningkatan kasus kriminalitas di Yogyakarta. Banyak tersangka yang merupakan remaja pelajar. Meskipun tidak diketahui secara pasti jumlah geng yang melakukan kriminalitas. Namun banyaknya nama geng sekolah yang beredar di media sosial membuat banyak warga menjadi resah. Seiring meningkatnya aksi Klithih ini diyakini karena faktor banyaknya kemunculan geng-geng tersebut. Geng-geng tersebut ikut serta dalam meningkatnya aksi kriminalitas yang tercatat di kepolisian. Perbuatan Klithih sudah merajalela dan terjadi sampai ke daerah pinggiran Kota Yogyakarta seperti di daerah Sleman dan Bantul. Klithih sebagian besar dilakukan oleh sekelompok murid dari Sekolah Menengah Atas (SMA) ataupun Sekolah Menengah Kejuruan (SMK) bahkan ada tersangka pelaku Klithih yang usia Sekolah Menengah Pertama (SMP). Banyak faktor yang menjadi latar belakang aktor melakukan Klithih. Padahal tindakan Klithih dapat menjerumuskan pelakunya pada tindakan hokum pidana. Hal ini disebabkan karena Klithih merupakan tindakan kejahatan dan kekerasan yang bisa melukai orang lain. Biasanya sekumpulan remaja ini beroperasi pada siang hari hingga sore hari saat mereka sudah pulang sekolah, namun tak jarang juga mereka beroperasi pada malam hari. Akhirakhir ini aksi tersebut banyak terjadi di malam hari. Sasaran mereka adalah memusuhi kumpulan remaja lainnya yang pada awalnya karena faktor sepele. Faktor pengaruh lingkungan pertemanan yang kurang baik juga mendorong para remaja ini untuk berbuat criminal Klithih tersebut.

Masalah antar kelompok ataupun geng sekolah karena ingin mencari eksistensi atau popularitas merupakan salah satu penyakit yang menyebabkan tindak kriminal tersebut, termasuk kematian para pelajar di Yogyakarta yang terjadi. Para korban aksi tersebut kebanyakan tidak tahu-menahu kesalahan ataupun dosanya. Klithih sendiri adalah kegiatan yang dilakukan segerombolan remaja yang rata-rata usia pelajar untuk mencari target musuh untuk disakiti, disiksa bahkan dibunuh. Kalau dahulu target aksi tersebut adalah geng yang bersaing untuk mendapatkan nama dan eksistensi, kalau aksi sekarang siapapun akan diserang yang penting aksi mereka terliput media. Dengan kata lain aksi tersebut selain menyebarkan ancaman juga menyebarkan ketakutan dan keresahan kepada masyarakat. Pemberitaan kriminal sekelompok pelajar baik di media massa maupun media sosial membuat citra Kota Yogyakarta sebagai kota pelajar mulai dipertanyakan. Fenomena klithih atau nglithih bukan lagi bermakna "cari angin" sambil mencari barang bekas di Pasar Klitikan yang terletak di Yogyakarta. Klithih dulunya memiliki makna positif yaitu 
mencari kegiatan untuk mengisi waktu luang ataupun untuk membunuh waktu senggang. Namun makna Klithih sekarang menjadi kelanjutan budaya negative yakni dari budaya tawuran pelajar. Budaya tawuran ini sudah muncul tahun 80-an sampai dengan 90-an. Kemudian akhir-akhir ini, Klitih berubah makna menjadi aksi kekerasan dengan senjata tajam atau kegiatan kriminal anak di bawah umur di luar kelaziman yang merupakan manifestasi dari konflik sosial masyarakat(Ahmad Fuadi, 2019:91).

\section{Metode}

Metode yang digunakan adalah literature review atau kajian pustaka dari berbagai sumber yang ada seperti buku rujukan Patologi Sosial karya Kartini Kartono, dan lain sebagainya berbagai artikel jurnal ilmiah baik itu online maupun cetak, media massa baik itu online maupun cetak, sumbersumber berita yang valid dan terpercaya serta sumber lain yang relevan untuk digunakan di dalam kajian mengenai klithih di Kota Yogyakarta. Jenis penelitian ini adalah penelitan kepustakaan (library research), yaitu serangkaian penelitian yang berkenaan dengan metode pengumpulan data pustaka, atau penelitian yang obyek penelitiannya digali melalui beragam informasi kepustakaan (buku, ensiklopedi, jurnal ilmiah, koran, majalah, dan dokumen). Penelitian kepustakaan atau kajian literatur (literature review, literature research) merupakan penelitian yang mengkaji atau meninjau secara kritis pengetahuan, gagasan, atau temuan yang terdapat di dalam tubuh literatur berorientasi akademik (academic-oriented literature), serta merumuskan kontribusi teoritis dan metodologisnya untuk topik tertentu. Dalam hal ini adalah topik mengenai deviasi sosial yakni klithih.

Fokus penelitian kepustakaan adalah menemukan berbagai teori, hukum, dalil, prinsip, atau gagasan yang digunakan untuk menganalisis dan memecahkan pertanyaan penelitian yang dirumuskan. Adapun sifat dari penelitian ini adalah analisis deskriptif, yakni penguraian secara teratur data yang telah diperoleh, kemudian diberikan pemahaman dan penjelasan agar dapat dipahami dengan baik oleh pembaca. Pendekatan yang digunakan dalam penelitian ini adalah pendekatan filosofis dan sosiologis. Pendekatan filosofis dan sosiologis merupakan pendekatan yang dilakukan untuk melakukan penalaran dan penyusunan suatu data secara sistematis berdasarkan sudut pandang tertentu (dalam hal ini sudut pandang yang digunakan adalah sudut pandang sejarah adanya klithih, penyebab klithih dan solusi mengatasi terjadinya klithih. 


\section{Hasil dan Pembahasan}

Kenakalan remaja adalah perilaku yang melanggar nilai, norma, aturan, atau hukum dalam masyarakat yang dilakukan pada usia remaja atau transisi masa anak-anak ke dewasa. Sumiati (2009) mendefinisikan kenakalan remaja adalah suatu perilaku yang dilakukan oleh remaja dengan mengabaikan nilainilai sosial yang berlaku di masyarakat. Para ahli pendidikan sependapat bahwa remaja adalah mereka yang berusia 13 tahun sampai dengan usia 18 tahun. Pada usia tersebut, seseorang sudah melampaui masa kanak-kanak, namun masih belum cukup matang untuk dapat dikatakan dewasa. Ia berada pada masa transisi dan pencarian jati diri, yang karenanya sering melakukan perbuatanperbuatan yang dikenal dengan istilah kenakalan remaja. Kenakalan remaja dinamakan lain dengan Juvenile Deliquency. Perbuatan tersebut akan merugikan dirinya sendiri maupun orang lain yang ada di sekitarnya. Contoh kenakalan remaja tersebut antara lain membolos sekolah, tawuran pelajar, pencurian, penipuan, balapan liar, membolos sekolah, berkelahi dengan teman, pemakaian obat-obatan terlarang, menonton tayangan untuk usia dewasa dan kegiatan lainnya yang dilakukan oleh para remaja.

\section{Klithih Dalam Paradigma Kenakalan Remaja}

Dalam pandangan patologis sosial, Kenakalan remaja (Juvenile Delinquency) diposisikan sebagai sumber patologis sosial yang dimana semua tingkah laku dari remaja merupakan hal-hal yang bertentangan dengan norma, stabilitas, moral, disiplin, dan hukum di lingkungan sosial. Masa remaja identik dengan sifat pembangkangan atau pemberontakan dalam diri para remaja. $\mathrm{Hal}$ ini disebabkan oleh pencarian jati diri atau identitas yang dilakukan oleh para remaja. Hal ini menimbulkan suatu gejala sosial yang bersifat destruktif atau merusak. Pemberontakan remaja yang bersifat destruktif melahirkan perbuatan yang dianggap sebagai kenakalan remaja. Sehingga pengertian kenakalan remaja (Juvenile Delinquency) secara khusus diartikan sebagai anak-anak muda yang melakukan kejahatan karena adanya motivasi untuk mendapatkan perhatian dari orang lain, status sosial, dan penghargaan dari lingkungannya.

Remaja delinkuen atau pelaku kenakalan remaja mengalami Defisien Moral / Defek moral. Defisien Moral yakni suatu kondisi dimana suatu individu yang hidupnya delinkuen (nakal, jahat) selalu melakukan kejahatan 
dan bertingkah laku a-sosial, namun tanpa mengalami penyimpangan atau gangguan pada fungsi inteleknya. Hanya saja inteleknya tidak berfungsi, sehingga terjadi pembekuan moral yang kronis. Penyimpangan-penyimpangan yang dilakukan remaja delinkuen cenderung bersifat psikotis dan mengalami regresi dalam relasi kemanusiaan sehingga sering melakukan kejahatan, kekerasan, dan melanggar hukum.

\section{Klithih Dari Sudut Pandang Konflik}

Kehidupan sosial selalu identik dengan konflik. Dimanapun dan kapanpun kita selalu menjumpai konflik. Konflik merupakan gejala sosial yang muncul dalam kehidupan masyarakat sosial, dimana konflik memiliki sifat yang inheren yang memiliki arti bahwa konflik akan senantiasa ada dalam setiap ruang dan waktu, kapan saja, dan juga dimana saja. Istilah "konflik" secara etimologis berasal dari Bahasa Latin "con" yang memiliki arti bersama dan "fligere" yang berarti benturan atau tabrakan. Secara umum, istilah konflik sosial mengandung berbagai fenomena yang meliputi pertentangan dan pertikaian antara seseorang ataupun kelompok terhadap pihak lain. Konflik merupakan suatu keadaan yang muncul akibat dari adanya pertentangan antara kehendak, nilai, dan tujuan yang ingin dicapai masing-masing pihak yang berkonflik. Hal ini dapat menyebabkan suatu kondisi yang tidak nyaman baik di dalam diri individu maupun antar kelompok.

\section{Jenis-Jenis Konflik}

Ada beberapa bentuk konflik di dalam kehidupan sosial masyarakat. Hal ini dapat diklarifikasikan sebagai berikut. Berdasarkan sifatnya konflik dibagi menjadi dua yakni konflik konstruktif dan konflik destruktif. Konflik konstruktif adalah konflik ini merupakan konflik yang muncul akibat dari adanya perbedaan pendapat dari kelompok-kelompok dalam menghadapi suatu permasalahan. Konflik konstruktif bersifat fungsional karena konflik ini akan menghasilkan suatu konsensus dari berbagai pendapat yang bermunculan dan dapat menghasilkan suatu bentuk perubahan lebih baik. Sedangkan Konflik destruktif merupakan konflik yang muncul akibat dari adanya perasaan tidak senang, rasa benci, dan dendam dari seseorang ataupun kelompok terhadap pihak lain. Konflik ini berujung pada hilangnya nyawa seseorang atau bahkan menghilangkan harta benda pihak yang berkonflik. 
Selanjutnya konflik berdasarkan posisi pelaku yang berkonflik dibagi menjadi konflik vertikal, konflik horizontal dan konflik diagonal. Konflik vertikal merupakan konflik yang terjadi antar komponen masyarakat yang terletak dalam satu strukturyang memiliki tingkatan/hierarki. Sedangkan konflik horizontal merupakan konflik yang terjadi antara seseorang ataupun kelompok terhadap pihak lain yang memiliki kedudukan relatif sama. Selanjutnya konflik diagonal merupakan konflik yang terjadi karena terdapat adanya ketidakadilan alokasi sumber daya ke seluruh organisasi sehingga menimbulkan pertentangan yang cenderung ekstrim.

\section{Faktor-Faktor Penyebab Konflik}

Konflik dapat terjadi karena disebabkan oleh beberapa faktor yang memicu. Menurut Soerjono Soekanto terdapat beberapa faktor penyebab terjadinya konflik, antara lain perbedaan antar individu, perbedaan kebudayaan dan perbedaan kepentingan. Perbedaan antar individu yakni antara pihak individu satu dengan yang lain pasti memiliki beragam perbedaan meliputi perbedaan pendirian dan juga keyakinan. Adanya perbedaan pendirian dan keyakinan inilah yang dapat menimbulkan adanya bentrokan yang terjadi diantara pihak yang berkonflik. Selanjutnya perbedaan kebudayaan yakni danya perbedaan pendirian dan keyakian antar individu dilatarbelakangi karena adanya pola- pola kebudayaan yang berbeda.

Perbedaan kebudayaan juga dapat menghasilkan sikap etnosentrisme, dimana seseorang akan menganggap bahwa kelompoknya sendirilah yang paling baik. Hal tersebut dapat memicu terjadinya konflik jika setiap orang memiliki sikap etnosentrisme yang hanya menganggap bahwa kelompoknya palinya paling baik dan tidak bisa menghargai kelompok yang lain. Terakhir yakni perbedaan kepentingan. Beragam individu di lingkungan sosial ini pasti juga memiliki beragam tujuan dan juga kepentingan yang hendak dicapai. Hal itu mengakibatkan tidak sedikit individu maupun kelompok yang akan melakukan apapun demi tujuan dan kepentingannya dapat tercapai, salah satunya adalah dengan cara berkonflik. Adanya perbedaan-perbedaan yang ada di dalam setiap diri individu meliputi perbedaan pendirian, perbedaan kebudayaan, dan juga perbedaan kepentingan yang dapat menimbulkan suatu konflik, maka akan menghasilkan suatu perubahan sosial. Perubahan sosial yang terjadi di masyarakat ini dapat mempengaruhi sistem nilai-nilai yang berlaku di dalam kehidupan sosial masyarakat. 


\section{Tahapan Konflik}

Dalam proses terjadinya sebuah konflik, akan melalui yang disebut dengan penahapan konflik, terdiri dari lima tahapan yaitu:

a. Sebelum konflik

Ini merupakan periode dimana terdapat suatu ketidak sesuaian sasaran diantara dua belah pihak atau lebih, sehingga timbul lah sebuah konflik. Konflik tersembunyi dari pandangan umum, meskipun satu pihak atau lebih mengetahui potensi terjadinya konfrontasi. Mungkin terdapat ketegangan hubungan diantara beberapa pihak atau keinginan untuk menghindari kontak satu sama lain pada tahap ini. Pada fenomena Klithih biasanya muncul rasa tidak suka karena saling ejek antar geng sekolah. Akan tetapi Klithih yang dulu ketika hanya terjadi antar geng sekolah, untuk beberapa tahun belakangan ini Klithih lebih sering menyerang masyarakat umum di jalanan, penyebabnya antara lain sebagai ajang pembuktian ataupun syarat untuk ketika memasuki suatu geng.

b. Konfrontasi

Pada tahap ini konflik terjadi semakin terbuka. Jika hanya satu pihak yang merasa ada masalah. Mungkin para pendukungnya mulai melakukan aksi demonstrasi atau perilaku konfrontatif. Pertikaian atau kekerasan pada tingkat rendah lainnya terjadi diantara kedua belah pihak. Masing-masing pihak mungkin mengumpulkan sumber daya dan kekuatan dan mencari sekutu dengan harapan dapat meningkatkan konfrontasi dan kekerasan. Hubungan diantara kedua belah pihak menjadi sangat tegang, mengarah pada polarisasi antara para pendukung di masing-masing pihak. Kemudian setelah terjadi ejek-ejek antar geng sekolah, selanjutnya anggota geng yang merasa ada masalah mulai mengumpulkan temannya untuk melakukan serangan kepada geng sekolah lain yang dianggap sebagai musuhnya.

c. Krisis/ Eskalasi Konflik

Ini merupakan puncak konflik, ketika ketegangan dan kekerasan terjadi paling hebat. Dalam konflik skala besar, ini merupakan periode perang, ketika kedua belah pihak jatuh korban dan saling membunuh. Komunikasi normal diantara kedua belah pihak kemungkinan terputus. Pernyataan-pernyataan umum cenderung menuduh dan menentang pihakpihak lainnya. Pada bagian ini, terjadilah penyerangan yang dilakukan pelaku Klithih terhadap anggota geng sekolah lain. Dalam penyerangan ini tak jarang mengakibatkan luka fatal bahkan sampai berujung kematian. 
Salah satu contoh kasus yang pernah terjadi yaitu pada satu Minggu sore di tahun 2019, Wawan bersama sembilan teman satu gengnya Respekakronim dari Religius/ Remaja Islam Perempatan Kapten Tendean Yogyakarta, berboncengan dengan lima motor. Mereka terbakar amarah akibat ejekan anggota geng musuh saat menonton pertandingan futsal antar sekolah sepulang dari kompetisi futsal hari itu, Wawan mengejar sejumlah anggota geng musuh berbekal celurit dan gir yang diikatkan dengan tali. Aksi itu menewaskan Egy Hermawan. Siswa sepantaran Wawan itu terkena luka bacok di perut dan rusuk.

Wawan ditangkap polisi, kembali dikeluarkan dari sekolah, dan dihukum empat tahun penjara. Ia kini menyesal dan tak ingin anak-anak lain terjebak hal yang sama dengannya. "Nggak usah (ikut-ikutan geng), nggak dapet apa-apa juga sebenarnya. Rugi sendiri," ucapnya kepada kumparan di Lembaga Pembinaan Khusus Anak Wonosari, Yogyakarta, Jumat, 07 Februari 2019. Klithih terhadap pengguna jalan juga sama, mereka menggunakan senjata yang dapat melukai korbannya mulai dari luka ringan sampai kematian.

d. Dampak Konflik

Suatu konflik pasti akan meninggalkan akibat. Satu pihak mungkin menaklukkan pihak lain, atau mungkin melakukan gencatan senjata. Satu pihak mungkin menyerah dengan sendirinya, atau menyerah atas desakan pihak lain. Kedua belah pihak mungkin setuju untuk bernegosiasi dengan atau tanpa perantara. Suatu pihak yang mempunyai otoritas atau pihak ketiga yang mungkin lebih berkuasa memaksa dua belah pihak untuk menghentikan pertikaian. Apapun keadaannya, tingkat ketegangan, konfrontasi dan kekerasan pada tahap ini agak menurun, dengan kemungkinan adanya penyelesaian. Pada kasus Klithih antar pelajar tentu berdampak pada munculnya korban, dendam antar geng, dan sebagainya. Sedangkan pada Klithih yang dilakukan kepada pengguna jalan maka akan mengakibatkan rasa kuatir ketika harus keluar malam karena merasa takut jika pelaku Klithih tiba- tiba muncul. Selain itu Klithih yang dilakukan kepada kepada masyarakat seringkali tidak mendapatkan hukuman yang membuat kawanan pelaku jera. Hal itu juga disebabkan karena biasanya pelaku Klithih berusia dibawah umur.

e. Pasca konflik/ De-eskalasi Konflik

Situasi ataupun diselesaikan dengan cara mengakhiri berbagai macam konfrontasi kekerasan, ketegangan berkurang dan hubungan 
mengarah pada situasi normal diantara kedua belah pihak. Namun isuisu dan masalah-masalah yang timbul karena sasaran mereka yang saling bertentangan tidak diatasi dengan baik, tahap ini sering kembali lagi menjadi situasi prakonflik. Biasanya ketenangan terjadi ketika sudah jarang terjadi aksi Klithih, namun untuk aksi Klithih yang dilakukan antar geng sekolah tidak bisa hilang begitu saja, karena bisa memunculkan dendam. Selain itu juga ketika sudah memasuki geng yang melakukan Klithih, tidak bisa mudah keluar dari lingkaran pergaulan itu. Kemudian Klithih yang terjadi kepada pengguna jalan atau masyarakat biasanya setelah tidak ada aksi Klithih mereka akan merasa lebih tenang. Namun Klithih bisa saja terjadi lagi pada tahun-tahun berikutnya.

\section{Aksi Klithih di Yogyakarta}

Secara definisi, belum ada keseragaman untuk mendefinisikan pengertian klithih secara pasti. Dalam Bahasa Jawa, klithih merupakan sebuah kosa kata yang berarti sebuah kegiatan dari seseorang yang keluar rumah dimalam hari tanpa tujuan. Sekarang ini, makna klithih diatribusikan sebagai perilaku remaja yang identik dengan kekerasan di jalan pada malam hari. Ini senada dengan pernyataan Kapolda DIY, Brigjend Pol Ahmad Dofiri M. Si bahwa klithih memiliki unsur yang sama yakni pelakunya pelajar (remaja), korbannya pelajar (remaja) dan menggunakan sepeda motor.

Klithih dalam pemahaman bahasa Jawa didefinisikan pada perilaku seseorang di malam hari ketika terbangun dan merasa lapar, tetapi di rumah tidak ada apapun yang bisa dimakan. Apa yang dilakukan orang tersebut adalah mencari apa saja yang bisa dimakan. Perilaku itulah yang dalam Kamus Bahasa Jawa disebut klithih. Makna klithih kemudian meluas untuk menandai perilaku yang juga bersifat mencari cari. Saat ini klithih digunakan untuk mengatribusi perilaku anak sekolah yang tergabung dalam gank sekolah dan mereka mencari cari "musuh" atau mencari cari "masalah", dimana mereka yang dianggap musuh adalah sesama pelajar di sekolah yang lain. Klithih dilakukan oleh sekelompok pelajar di sekolah yang bergabung dalam gank sekolah. Selepas sekolah anak anak geng sekolah ini melakukan "mubeng" (berkeliling ke tempat tempat tertentu dengan mengendarai sepeda motor beramai ramai). Dalam mubeng mereka bisa saja bertemu siswa sekolah lain yang selama ini dianggap sebagai musuh mereka, jika itu terjadi, siswa dari sekolah lain ini bisa dianiaya tanpa sebab. 
Klithih merupakan salah satu kriminalitas anak yang akhir-akhir ini sangat meresahkan masyarakat Yogyakarta. Aksi Klithih di Yogyakarta dilakukan oleh geng yang berbasis pelajar sekolah (Arifin, 2017). Klithih juga terjadi di daerah sekitaran Yogyakarta (khususnya Bantul dan Sleman). Fenomena ini biasanya terjadi terhadap anak muda usia 14 tahun hingga 19 tahun yang merupakan pelajar Sekolah Menengah Pertama dan Sekolah Menengah Atas. Pada umumnya, pelaku Klithih akan mengincar target, yang mana target tersebut merupakan siswa SMA/SMP pesaing atau anggota geng pesaing di daerah yang dianggap sepi kemudian pelaku melakukan bullying secara fisik terhadap pelaku. Terkadang pelaku juga mengambil barang milik korban bahkan termasuk harta benda sehingga terkadang kejahatan ini termasuk perampokan. Tidak jarang juga korban Klithih juga meninggal dunia akibat menderita siksaan fisik yang cukup kuat. Akhir-akhir ini Klithih yang terjadi di Yogyakarta banyak yang memakan nyawa, banyak pelaku yang asal membunuh atau melukai dengan senjata tajam kepada siapapun yang berjalan/mengendarai kendaraan dalam keadaan sepi atau saat dini hari secara acak demi kepuasan pribadi.

Klitih atau Klithih (klithihan atau nglithih) merupakan sebuah (kosa) kata dari Bahasa Jawa gaya Yogyakarta yang memiliki arti sebuah kegiatan atau aktivitas dari seseorang atau sekelompok orang yang keluar rumah di malam hari tanpa tujuan atau hanya sekedar jalan-jalan, mencari atau membeli makan, nongkrong di suatu tempat dan lain sebagainya. Klithih jika dialih bahasakan ke dalam kosa kata bahasa Indonesia bisa disamakan dengan kata keluyuran. Namun kini kata Klithih disamakan dengan kegiatan menjurus ke hal atau tindakan yang kurang baik. Hal ini cukup membuat pemakluman karena viralnya orang menyebut aksi anak remaja tanggung yang melakukan aksi melukai dengan sebutan klithih. Penyebutan kata Klithih yang menjurus hal negatif juga mendapat penolakan dari banyak pihak, karena arti sebenarnya dari Klithih ini bukan tindakan kriminalitas. Sekarang makna Klithih kemudian mengalami pergeseran menjadi aksi kekerasan dengan senjata tajam atau kegiatan kriminalitas anak di bawah umur di luar kelaziman. Kata Klithih muncul untuk menggantikan kata tawuran, setelah maraknya peristiwa pembacokan pada tahun 2011-2012. Klithih sempat redup sekitar tahun 2013, ketika kepolisian setempat mampu meredam aksi kekerasan yang dilakukan oleh kalangan pelajar ini hingga jauh berkurang. Namun istilah ini kembali populer setelah tahun 2014, korban kembali berjatuhan akibat Klithih. Dimulai dari keributan satu remaja berbeda sekolah dengan remaja yang lain kemudian berlanjut dengan melibatkan komunitas masing-masing. Aksi saling membalas terus terjadi dan 
sengaja dipelihara turun temurun (menjadi tradisi). Permasalahannya, motif Klithih amat beragam dan yang mengerikan, korban mereka bisa jadi amat acak.

Bila ditelusuri kapan pertama kali perkara Klithih ada, menurut arsip Harian Kompas kejadian kriminal yang melibatkan remaja itu sudah muncul pada tahun 1990-an. Harian Kompas mencatat pada 7 Juli 1993, Kepolisian Wilayah (Polwil) DIY mulai memetakan keberadaan geng remaja di Yogyakarta. Pihak Polwil mengklaim sudah memiliki informasi soal keberadaan geng remaja dan kelompok anak muda yang sering melakukan aksi kejahatan di Yogyakarta. Kemudian pada tahun 2000-an, fenomena tawuran mulai menjamur di Yogyakarta. Sampai-sampai membuat Walikota Yogyakarta saat itu Herry Zudianto geram. Herry mengancam bila ada pelajar di sana yang terlibat tawuran maka akan dipulangkan ke orang tuanya, atau dikeluarkan sekalian. Imbauan itu sempat dinilai berhasil mengurangi aksi kekerasan remaja.

Pada awalnya, Klithih hanyalah berupa kegiatan perundungan antar geng sekolah yang terjadi di kawasan Daerah Istimewa Yogyakarta dan sekitarnya. Namun, semakin lama, Klithih berkembang menjadi kegiatan perampokan yang dilakukan oleh sekelompok geng (premanisme) yang targetnya berkembang dari geng musuh menjadi masyarakat awam. Hal yang sering dilakukan yaitu kegiatan Klithih selalu dilakukan di tempat sepi dan terjadi pada malam hari. Kasus Klithih pada dasarnya merupakan fenomena anak muda di Yogyakarta yang ingin mencari jati diri atau pengakuan terutama dari lingkungan persahabatan mereka. Untuk membuktikan itu, terkadang mereka membutuhkan barang bukti berupa barang milik geng pesaing atau setidaknya melakukan perundungan terhadap geng pesaing.

\section{Faktor Penyebab Klithih}

Ada banyak faktor penyebab terjadinya Klithih yang dalam artian merujuk pada kegiatan yang negatif. Faktor penyebab terjadinya Klithih bisa berupa latar belakang keluarga yang bermasalah, lingkungannya yang bermasalah, hubungan dengan kelompok, hubungan dengan lingkungan, serta karakter individu. Pertama, latar belakang keluarga yang bermasalah. Anak yang sedih dan kesal karena ditinggal pergi ayahnya. Semenjak kepergian ayahnya, ia hanya tinggal bertiga dengan ibu dan adiknya. Kemudian, dia menjadi jauh dengan keluarganya, dan dekat dengan orang lain. Oleh karena itu, si anak ini menjadi lebih sering di luar rumah menghabiskan waktu bersama teman- temannya ketimbang diam di rumah. Karena merasa sudah tidak diperhatikan lagi, 
hal itu memicu anak untuk melakukan tindakan kekerasan. Selain itu, latar belakang orang tua yang pernah melakukan kekerasan dalam rumah tangga juga menjadi pemicu mengapa anak (remaja) bisa terlibat Klithih. Faktor kedua penyebab remaja berperilaku Klithih karena hubungan dengan kelompok. Faktor ini mengungkap bahwa anak remaja membutuhkan "pengakuan" dari teman sejawatnya. Namun sayangnya pengakuan itu didapat dari hal-hal yang negatif. Selain faktor hubungan dengan kelompok, aspek lingkungan juga mempengaruhi. Masih menurut penelitian Ahmad Fuadi dkk (2019), lingkungan yang cenderung membiarkan warganya, bisa membuat remaja bebas melakukan apa saja.

Faktor lingkungan dapat semakin membuat seorang pelajar berperilaku buruk apabila dalam pergaulannya, pelajar menemui sesama teman yang memiliki tingkat kenakalan yang sama. Kecenderungan cara berteman sekarang adalah kebanyakan dari individu-individu akan membentuk sebuah kumpulan tertentu dengan latar belakang dan tujuan tertentu, atau yang biasa disebut dengan geng. Dari geng atau perkumpulan ini kemudian akan membentuk identitas baru atas nama satu golongan dengan pandangan tertentu dan tujuan yang dimengerti oleh satu sama lain dalam satu kelompok tersebut. Kemudian yang terakhir adalah faktor karakter pribadi itu sendiri. Mereka yang melakukan Klithih, adalah kebanyakan mereka yang sulit mengendalikan emosi, mudah tersinggung ketika diganggu orang lain, dan cenderung agresif. Alasan mereka melakukan kekerasan salah satunya karena sebagai sarana pelampiasan karena ada masalah dengan orang tua dan balas dendam karena sudah diganggu oleh orang lain.

Beberapa faktor penyebab kejahatan yang dilakukan oleh pelaku aksi klithih di Kota Yogyakarta dan sekitarnya antara lain adalah sebagai berikut:

a. Faktor Sakit Hati dan Dendam

Perasaan sakit hati adalah semacam desakan batin yang senantiasa memerlukan tindakan pelampiasan. Apabila hal itu terus-menerus bergejolak di dalam hati dan pikiran seseorang, maka setiap kesempatan akan dimanfaatkan untuk membalaskan dendamnya. Penyebab dendam adalah sebuah perasaan yang lahir dari perasaan benci atau marah, yang sering kali dipendam secara rahasia. Perasaan dendam tak hanya buruk bagi kesehatan mental, namun juga memiliki efek negatif bagi kesehatan fisik. Pada dasarnya persoalan sakit hati adalah persoalan yang sangat bersentuhan dengan watak masing-masing orang. Tanpa kita sadari, apabila kita memiliki sikap watak pendendam, maka dalam kesehariannya, 
kapanpun perasaan kita tersakiti, maka secara tidak langsung kita akan berusaha untuk membalasnya. Faktor sakit hati atau dendam ini juga bisa terjadi di mana saja, bahkan dalam lingkungan keluarga sekalipun. Hal ini tergantung dari watak seseorang dan hubungannya dengan orang-orang di sekitarnya. Oleh karena itu, komunikasi yang baik dan lebih intens mungkin dapat menjadi solusi dari faktor ini.

b. Faktor Lingkungan

Di dalam lingkungan keluarga, kontrol dari orang tua terhadap anak sangatlah penting. Karena kurangnya pengawasan dari orang tua, membuat anak menjadi bebas sehingga memberi kesempatan bagi mereka untuk melakukan hal-hal yang tak diinginkan, seperti aksi klithih ini. Orang tua yang terlalu disibukkan dengan pekerjaan, seringkali membuat mereka lalai untuk melakukan kontrol terhadap anaknya. Perhatian dan kasih sayang kepada anaknya hanya diekspresikan dalam bentuk materi saja, padahal materi tidak dapat mengalahkan pentingnya kasih sayang dan perhatian orang tua. Selain itu juga dapat terjadi karena sebuah keluarga mengalami broken home atau perceraian, namun kedua orang tua yang bercerai tersebut sudah tidak mempedulikan anaknya lagi karena sibuk dengan keluarga barunya.

Pada dasarnya setiap orang menginginkan pengakuan, perhatian, pujian, dan kasih sayang dari lingkungannya, khususnya dari orang tua atau keluarganya. Karena secara alamiah orang tua dan keluarga memiliki ikatan yang sangat kuat. Pada saat pengakuan, perhatian, dan kasih sayang tersebut tidak mereka dapatkan di rumah, maka mereka akan mencarinya di tempat lain. Salah satu tempat yang paling mudah mereka temukan untuk mendapatkan pengakuan tersebut adalah di lingkungan teman sebayanya. Sayangnya, kegiatan-kegiatan negatif kerap menjadi pilihan anak-anak broken home tersebut sebagai cara untuk mendapatkan pengakuan tersebut.

c. Faktor Pengaruh Minuman Keras.

Pengonsumsi minuman keras secara berlebihan akan dapat mempengaruhi syaraf berfikirnya dan melahirkan suatu kepribadian yang menyimpang, dengan ciri-ciri sebagai berikut terlalu mengutamakan dan mementingkan diri sendiri, ketergantungan kepada seseorang atau orang lain, perasaan yang berlebih-lebihan terhadap kemampuan diri sendiri atau merasa dirinya jagoan. Pada dasarnya dengan pengaruh minuman keras, seseorang dapat melakukan suatu kejahatan tanpa disadari apakah 
tindakan tersebut benar atau salah. Kemudian yang terjadi adalah pelaku kejahatan tersebut bertindak diluar pemikiran yang normal ketika sedang berada dalam pengaruh minuman keras. Orang tersebut menjadi mudah tersinggung dan perhatian terhadap lingkungan juga terganggu, menekan pusat pengendalian diri sehingga yang bersangkutan menjadi lebih agresif. Apabila hal ini tidak terkontrol, akan menimbulkan tindakan-tindakan yang melanggar norma-norma dan sikap moral yang lebih parah lagi, dengan kata lain menimbulkan tindak pidana atau kriminal. Penggunaan minuman keras secara berlebihan dan tidak terkendali, akan menimbulkan berbagai masalah, baik bagi diri sendiri maupun orang lain atau lingkungan masyarakat sekitarnya. Pada dasarnya minuman keras sangat mempengaruhi bagi seseorang untuk melakukan kejahatan, termasuk kejahatan yang dilakukan oleh pelaku aksi klithih.

d. Minimnya pendidikan

Minimnya pendidikan dalam suatu lingkungan masyarakat dapat menimbulkan dampak terhadap masyarakat tersebut yaitu sikap kurang literasi dan kreatif sehingga menyebabkan kurangnya pengendalian diri untuk melakukan suatu kejahatan. Sebaliknya, ketersediaan pendidikan yang baik memungkinkan tingkah laku menyimpang dapat dicegah atau setidaknya dikendalikan. Salah satu tujuan pendidikan adalah realisasi transformasi nilai-nilai budaya yang baik dan benar dari generasi ke generasi berikutnya. Walaupun pendidikan yang minim dalam suatu lingkungan masyarakat dapat memungkinkan timbulnya para pelaku kejahatan, namun tidak secara mutlak dapat dikatakan bahwa faktor pendidikan ini merupakan penyebab utama timbulnya kejahatan yang dilakukan oleh pelaku aksi klithih khususnya di Daerah Istimewa Yogyakarta.

Pelaku aksi klithih tersebut. Namun di luar itu semua, faktor penyebab kejahatan yang diakukan oleh pelaku aksi klithih di Daerah Istimewa Yogyakarta mayoritas adalah faktor dari diri sendiri. Walaupun seseorang bergaul dengan teman sebaya yang banyak hal negatif akan tetapi orang itu tidak mengikutinya karena karena tidak ada sama sekali keinginan. Kemudian walaupun seseorang mendapat perhatian lebih dari keluarga, dan materi juga tercukupi akan tetapi jika orang tersebut memiliki hati yang kurang baik maka orang itu dapat melakukan kejahatan karena dorongan keinginan dari diri pribadi. Menurut salah satu tokoh, Sosiolog Kriminalitas Universitas Gajah Mada (UGM), Soeprapto menyebutkan kekerasan remaja terjadi karena pengaruh lingkungan 
sosial yang salah. Berikut ini adalah faktor-faktor yang menyebabkan terjadinya fenomena Klithih yaitu:

1) Ada pengaruh kuat kelompok sepermainan atau "peer group" ke arah perilaku kekerasan

2) Adanya pengaruh dari motor penggerak, misal kakak kelas dan alumni.

3) Menunjukkan eksistensi diri agar keberadaannya diakui.

4) Ada yang memanfaatkan keadaan psikologis remaja yang sedang berada dalam masa transisi biologis dan sosial.

5) Tindakan kekerasan itu muncul disebabkan kurangnya penanaman nilai budaya dan norma sosial.

6) Mereka tidak dapat membedakan perilaku yang baik dan perilaku yang buruk dan harus dihindari.

7) Penanaman nilai-nilai keagamaan hanya sampai pada sosialisasi, belum sampai ke internalisasi atau penghayatan.

8) Rata-rata seseorang yang gemar melakukan kekerasan memiliki kualitas kecerdasan emosional (EQ) hanya pada level pertama yakni memahami diri sendiri, belum sampai level kedua mampu mengendalikan diri. Apalagi level tiga, memahami orang lain, dan level empat, mengendalikan orang lain.

\section{Dampak Klithih}

a. Dampak positif geng klithih

1) Memperluas pergaulan

2) Sarana bertukar informasi

3) Menambah pertemanan

4) Mempererat solidaritas

5) Mengajarkan kerjasama

b. Dampak Negatif Klithih

1) Dapat menyebabkan luka yang parah bahkan kematian.

Klithih yang diartikan sebagian besar masyarakat sebagai aksi kekerasan atau kejahatan jalanan dengan senjata tajam atau tindaktanduk kriminal anak di bawah umur di luar kelaziman ini, dapat menyebabkan korbannya mengalami luka yang parah karena dilakukan dengan senjata tajam da tak jarang yang berujung hingga kematian. 
2) Dapat menyebabkan keresahan bagi masyarakat.

Dengan maraknya berita klithih yang memakan korban di beberapa daerah, menyebabkan masyarakat yang tinggal di daerah tersebut merasa was-was dan tidak nyaman. Keresahan tersebut terkadang membuat masyarakat takut untuk keluar malam hari di jamjam rawan yang biasanya adalah waktu klithih beraksi.

3) Merusak nama baik daerah yang bersangkutan.

Klithih yang beraksi memiliki daerah-daerah yang sengaja mereka jadikan tempat untuk dijadikan lokasi tindakan kriminal tersebut. Biasanya adalah daerah yang jalanannya sepi dan jauh dari keramaian kota sehingga mereka bisa melancarkan aksinya. Daerah yang di jadikan aksi klitih tersebut menyebabkan banyak orang berpandangan bahwa daerah tersebut tidak aman dan tidak adanya penjagaan yang ketat dari pihak yang berwajib sehingga bisa terjadi hal tersebut. Nama daerah tersebut menjadi hal yang tahu bagi masyarakat luar untuk tidak datang kesana dengan alasan takut dan tidak aman untuk dikunjungi. Dalam hal ini Kota Yogyakarta yang dikenal dengan citra kota pelajar dan kota pendidikan serta kota budaya menjadi tercemar karena sudah tidak aman lagi dengan adanya tindakan klithih tersebut.

4) Menurunkan kualitas anak penerus bangsa Indonesia.

Kasus klithih yang terjadi di beberapa daerah banyak melibatkan anak usia sekolah yang tentu saja menurunkan citra remaja masa kini. Mereka yang seharusnya menjadi generasi penerus bangsa yang membanggakan dan aktif dalam kegiatan sekolah dan masyarakat malah justru aktif dalam organisasi klithih. Dari banyak sumber menyebutkan bahwa, anak-anak sekolah ini menjadi target para pemimpin klithih untuk dijadikan boneka agar mau menuruti perintahnya dengan imbalan disegani lawan dan sehingga pemimpinnya akan merasa puas. Banyak juga kasus yang menyatakan bahwa para remaja ini melakukan klithih sebagai syarat dalam rekruitmen anggota baru dalam suatu genk agar di takuti oleh geng lawan.

5) Merusak persatuan dan kesatuan bangsa.

Dengan adanya geng yang saling membenci dan saling unjuk gigi untuk menunjukkan kekuatannya menyebabkan perpecahan dan permusuhan yang akhirnya membuat persatuan dan kesatuan menjadi lemah dan hancur. 
6) Mencemari nama baik sekolah atau instansi lembaga.

Remaja atau seseorang yang terlibat klithih akan mempengaruhi nama baik sekolah atau instansi yang telah tergabung dalam klithih tersebut.

\section{Simpulan}

Maraknya aksi klithih atau kekerasan di jalan yang dilakukan oleh anak muda akhir-akhir ini, dinilai cukup meresahkan. Dari kasus penyerangan dan penusukan kepada rombongan pelajar SMA Muhammadiyah 1 Yogyakarta dapat diketahui bahwa kejadian bermula karena adanya kontak mata atau saling melirik sehingga memancing emosi salah satu pihak yang tidak lain adalah kelompok klithih. Apabila di analisis menggunakan sosiologi konflik, dilihat dari sudut pelaku, mereka merupakan remaja berusia antara 15 tahun hingga 18 tahun. Dampak dari aksi mereka sangat luar biasa meresahkan, mulai dari pengerusakan, melukai orang lain, bahkan hingga ada korban yang meninggal dunia. Alasan remaja melakukan hal itu karena untuk menunjukkan eksistensi diri maupun kelompok.

Para pelaku klithih sebenarnya terdesak dalam sebuah proses sosial, sehingga mereka mengungkapkan kekecewaan dan membangun identitasnya dengan tindakan kekerasan-kekerasan itu. Untuk mengetahui penyebab aksi klithih, harus dilihat dari proses terbentuknya, yakni proses-proses peminggiran mereka dan bagaimana mereka tersingkir dari lingkungannya. Setelah proses pembentukan itu terjadi, termasuk membentuk kelompok-kelompok, proses selanjutnya adalah aksi berupa tindakan kekerasan. Para pelaku melaksanakan aksinya karena mereka ingin memiliki identitas, kekuasaan, bahkan mungkin menginginkan keuntungan dari segi ekonomi. Pelaku klithih muncul dari masyarakat yang tertutup, dalam artian tidak menerima kelompok-kelompok yang tidak sejalan dengan visi dan misi masyarakat.

Para pelaku klithih biasanya merupakan orang-orang yang tersingkir, bukan hanya dari norma tapi juga dari struktur ekonomi, pendidikan, dan sosial. Karena kematangan emosi yang buruk dan munculnya judgement atau penghakiman oleh masyarakat yang kemudian tertanam dalam pikiran mereka, membentuk suatu keyakinan bahwa mereka memang remaja yang seperti itu. Hasilnya, mereka mereproduksi penilaian masyarakat tersebut dengan wujud tindakan kekerasan yang seperti klithih. Resolusi konflik dari kasus klithih adalah dengan jalan hukum karena pelaku klithih terbukti melakukan tindak 
pidana yaitu penyerangan, pengeroyokan, penusukan hingga mengilangkan nyawa orang lain. Hal ini dilakukan agar memberikan efek jera pada pelaku dan agar kasus seperti itu tidak terulang kembali.

Klithih sebenarnya dapat diatasi atau dihilangkan oleh masyarakat. Salah satu halnya dengan meningkatkan toleransi di masyarakat. Dengan masyarakat yang lebih toleran, mereka akan menjadi lebih terbuka pada sesuatu yang berbeda. Dengan toleransi tersebut kondisi masyarakat menjadi lebih sehat secara sosial psikologi. Di sisi lain peran pemerintah memperbanyak ruang publik di masyarakat terlebih di perkotaan karena tempat-tempat bermain atau arena-arena aktualisasi diri remaja mulai hilang. Dengan dibangunnya ruang publik, remaja dapat melakukan hal-hal yang positif. Perhatian dan kasih sayang orang tua sesungguhnya merupakan faktor utama untuk mencegah anak terjerumus dalam kelompok klithih. Relasi yang buruk dengan orangtua bahkan pernah memiliki riwayat kekerasan fisik di keluarga menjadikan para pelaku memiliki komitmen kuat dengan geng atau kelompok klithih karena merasa senasib.

\section{Ucapan Terima Kasih}

Ucapan terima kasih penulis haturkan kepada Jurnal Humanika Mata Kuliah Universiter Lembaga Penjaminan Mutu dan Pengembangan Pendidikan Universitas Negeri Yogyakarta yang telah mempublikasikan artikel ini.

\section{Daftar Pustaka}

Ahmad, F., Muti'ah, T. \& Hartosujono. (2019). Faktor-faktor determinasi perilaku

Klitih. Jurnal UST Jogja. 09(2). 88-98. Diakses 27 Januari 2020 dari http:// jurnal.ustjogja.ac.id/index.php/spirit/article/download/6324/2922.

Anonim. (2019). Pengertian konflik menurut para ahli lengkap. Ruangguru.com [online]. Diakses 27 Januari 2020 dari https://www.ruangguru.co.id/23pengertian-konflik-menurut-para-ahli-lengkap/.

Anonim.(n.d).BABIVHasilpenelitiandanpembahasan. Diakses24Januari2020dari http://repository.umy.ac.id/bitstream/handle/123456789/15835/9. BAB\%20IV.pdf? sequence $=8 \&$ isAllowed $=\mathrm{y}$.

Anonim. (2020). Mencari jati diri lewat klitih. kumparanNEWS [online]. Diakses 20 Januari 2020 dari https://kumparan.com/kumparannews/mencari- 
Kenakalan remaja klithih yang mengarah pada konflik sosial dan kekerasan di Yogyakarta (Datu Jatmiko)

jati-diri-lewat-Klitih-1soPLxOPfpm.

April, K.S. (2017). Persepsi guru smp muhammadiyah 5 yogyakarta terhadap dampak negatif pasca maraknya aksi klitih di kalangan pelajar. Diakses 28 Januari 2020 dari http://repository.upy.ac.id/1653/1/ARTIKEL\%20KLITIH. pdf.

Dadan, S., Humaedi, S. \& Meilanny, B. S.. (2017). Kenakalan remaja dan penanganannya. Jurnal Penelitian \& PPM. 4(2). 129-389. Diakses pada tanggal 27 Januari 2020 dari http://jurnal.unpad.ac.id/prosiding/ article/download/14393/6947.

Hadi, U. (2016). Pelajar aksi klitih bantul divonis lebih ringan dari tuntutan jaksa, begini alasannya. Tribunjogja.com [online]. Diakses 26 Januari 2020 dari https://jogja.tribunnews.com/2017/01/13/pelajar-aksi-Klitihbantul-divonis-lebih-ringan-dari-tuntutan-jaksa-begini-alasannya.

Hidayah, K. (2016). Ini dugaan polisi terkait motif aksi klitih yang menewaskan adnan. Tribunjogja.com [online]. Diakses 27 Januari 2020 dari https:// jogja.tribunnews.com/2016/12/14/ini-dugaan-polisi-terkait-motif-aksiklithih-yang-menewaskan-adnan.

Lailatul, M. (2014). Konflik dalam lembaga pendidikan. Skripsi. UIN Sunan Ampel Surabaya. Diakses 29 Januari 2020 dari http://digilib.uinsby.ac.id/314/5/ Bab\%202.pdf.

Pamungkas,Z.(2018). Fenomenaklithihsebagaibentukkenakalanremajadalamperspektif budaya hukum di kota Yogyakarta. Diakses 11 Januari 2020 dari https:// dspace.uii.ac.id/bitstream/handle/123456789/11387/ZULFIKAR\%20 PAMUNGKAS\%2010410761.pdf? sequence=1\& isAllowed=y.

Riadi, M. (2017). Pengertian, jenis, penyebab, dan tahapan konflik. KajianPustaka. com [online]. Diakses 27 Januari 2020 dari https://www.kajianpustaka. com/2017/08/pengertian-jenis-penyebab-dan-tahapan-konflik. html?m=1.

Salam, F. (2016). Darurat Klitih Yogyakarta. Tirto.id [online]. Diakses 27 Januari 2020 dari https://tirto.id/darurat-Klitih-di-yogyakarta-cbH7.

Sarwono, R. B. (2017). Mengendalikan kegaduhan sosial "klithih" dengan Ketahanan keluarga. Diakses 11 Januari 2020 dari http://www.google. $\mathrm{co} . \mathrm{id} / \mathrm{url}$ ? sa $=\mathrm{t} \& \mathrm{rct}=\mathrm{j} \& \mathrm{q}=\mathrm{JURNAL} \% 20 \mathrm{KLITIH} \&$ source=web\& $\mathrm{c}-$ $\mathrm{d}=4$ \&ved=2ahUKEwix65GikpLoAhXZILcAHVPxAkMQFjADegQIARAB\&url=http $\% 3$ A\%2F\%2Fjournal2.um.ac.id\%2Findex. 
Humanika, Kajian IImiah Mata Kuliah Umum, Vol. 21. No. 2. (2021), 129-150

php\%2Fsembk\%2Farticle\%2Fdownload\%2F1285\%2F659\&usg=AOvVaw2T6rE6vOnawd3mggh9_3_K.

Sudarsono. (2004). Kenakalan remaja (prevensi, rehabilitasi, dan resosialisasi). Rineka Cipta.

Sukmawati, I..F.. (2018). Kenakalan remaja yang berbau kekerasan, anarkis, dan merajalela. Diakses 24 Januari 2020 dari https://www.brilio.net/creator/ kitih-fenomena-kenakalan-remaja-yogyakarta-pantau-kegiatan-anakanda-022385.html

Syambudi, I. (2020). Pelajar di Jogja jadi pelaku klithih, salah keluarga atau sekolah?. Diakses 30 Januari 2020. https://tirto.id/pelajar-di-jogja-jadi-pelakuklitih-salah-keluarga-atau-sekolah-exgu

Zulfikar, P. (2018). Fenomena klitih sebagai bentuk kenakalan remaja dalam perspektif budaya hukum di kota Yogyakarta. Skripsi. Universitas Islam Indonesia Yogyakarta 